\title{
ANALISIS PENGARUH AKTIVITAS, LIKUIDITAS DAN SOLVABILITAS TERHADAP PROFITABILITAS PADA PERUSAHAAN KONSTRUKSI DAN BANGUNAN YANG TERDAFTAR DI BURSA EFEK INDONESIA
}

\author{
${ }^{1)}$ Yayan Hendayana, ${ }^{2)}$ Dianita Anjarini \\ Program Studi Manajemen, Fakultas Ekonomi Dan Bisnis \\ Universitas Islam As-Syafi'iyah \\ Email : 1)yayan_ha.feb@uia.ac.id
}

\begin{abstract}
The purpose of this study was to determine and analyze the effect of Activity (Working Capital Turnover / WCT), Liquidity (Current Ratio / CR), and Solvency (Debt to Asset Ratio / DAR) on profitability (Return On Asset / ROA). Determination of the sample using purposive sampling technique based on predetermined criteria obtained as many as 13 companies with a research period of 5 years (2015-2019). The test method uses panel data regression analysis with Eviews version 9. Based on the results it is known that WCT has a positive and insignificant effect on ROA, $C R$ has a significant positive effect on $R O A$, and DAR has a negative and insignificant effect on ROA of construction and building companies listed on the Indonesia Stock Exchange for 2015-2019 period.
\end{abstract}

Keyword : Working Capital Turnover, Current Ratio, Debt to Asset Ratio, Return on Asset

\section{PENDAHULUAN}

\subsection{Latar Belakang}

Perkembangan infrastruktur transportasi, sumber air dan konstruksi unit rumah tinggal dengan harga terjangkau pun menjadi faktor penggerak perkembangan sektor konstruksi dan bangunan ini, terlebih didukung oleh program pengembangan infrastruktur transportasi selama periode tahun 2015-2019, yang merupakan rencana pemerintah untuk mengembangkan infrastruktur transportasi di Indonesia. Jasa konstruksi mengalami pertumbuhan yang cukup pesat dan berdampak pada peningkatan persaingan diantara perusahaan-perusahaan sejenis.

Perusahaan konstruksi bangunan adalah perusahaan yang merancang dan membangun sarana maupun prasarana, meliputi pembangunan jalan raya, konstruksi jembatan, rumah, dan gedung. Secara umum perusahaan konstruksi bangunan melakukan proyek yang diperoleh berdasarkan tender. Proyek tersebut bisa berasal dari proyek yang digagas pemerintah untuk pembangunan nasional maupun dari pihak swasta atau asing. Sama halnya seperti perusahaan pada umumnya yaitu memiliki tujuan untuk memperoleh keuntungan (profit). Profit yang diperoleh dipakai untuk kegiatan operasional, mempertahankan kelangsungan hidup dan pengembangan perusahaan. Profitabilitas perusahaan menunjukkan tingkat pengembalian perusahaan yang dihasilkan dari aktiva yang digunakan perusahaan.

Berdasarkan data historis 10 tahun terakhir, kinerja empat BUMN konstruksi (PT Waskita Karya, Tbk, PT Adhi Karya, Tbk, PT PP Persero, Tbk dan PT Wijaya Karya, Tbk) mengalami fluktuasi cenderung menurun. Dari gambaran kinerja perusahaan tersebut, untuk mengetahui seberapa besar perusahaan mampu menghasilkan laba, peneliti akan 
menganalisis rasio profitabilitas dengan membandingkan laba bersih yang diperoleh dengan total kekayaan/aset perusahaan. Berikut adalah Persentase ROA dari 13 perusahaan konstruksi dan bangunan yang terdaftar di Bursa Efek Indonesia (BEI) periode tahun 2015 - 2019.

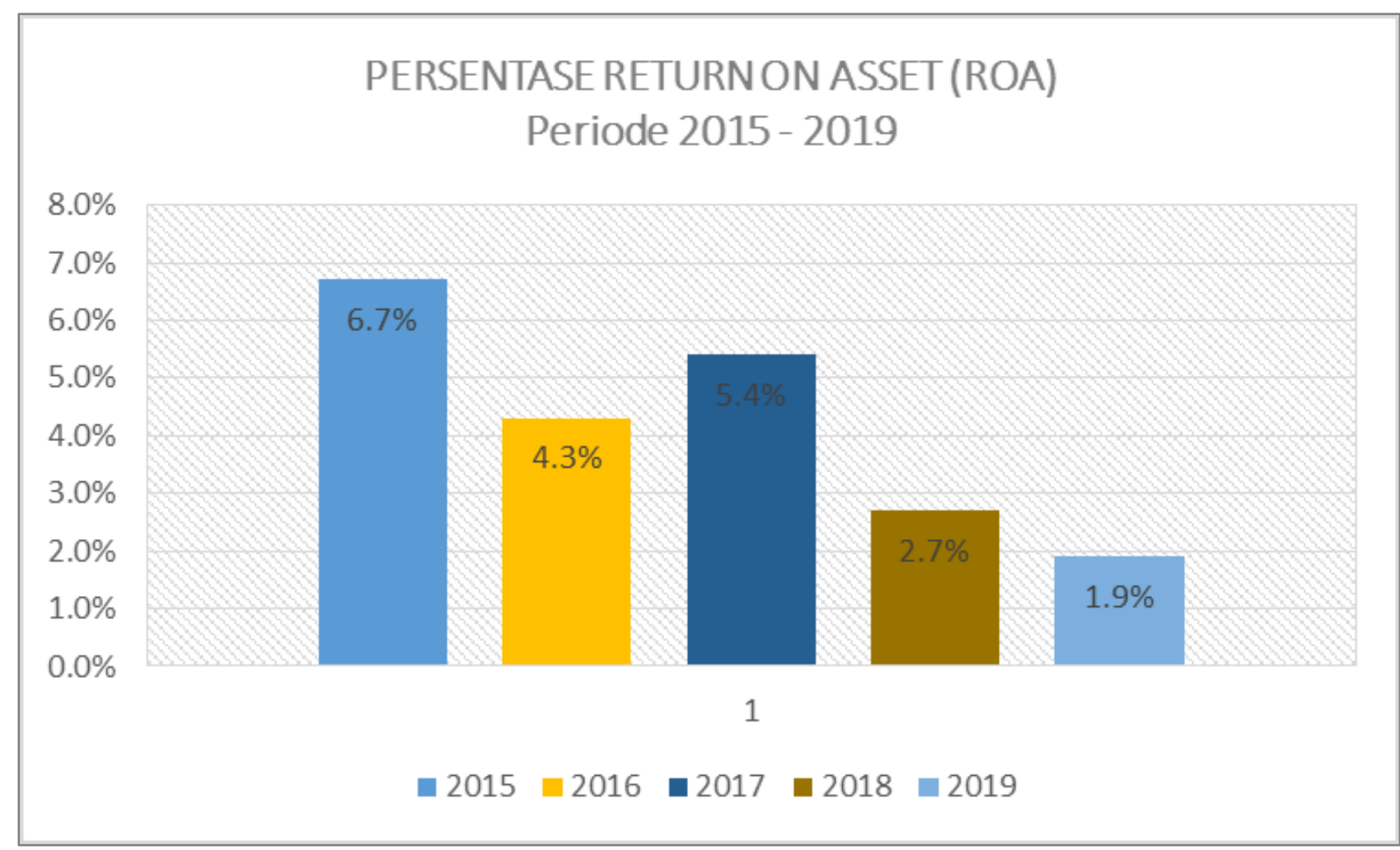

\section{Gambar 1. Return On Asset (ROA) Perusahaan Konstruksi \& Bangunan yang Terdaftar di Bursa Efek Indonesia Periode 2015 - 2019}

Sumber Data : Laporan Keuangan Perusahaan (Data Diolah)

Dari Grafik di atas, terlihat bahwa 13 perusahaan konstruksi \& bangunan yang terdaftar di BEI mengalami penurunan rata-rata ROA pada tahun 2016 yaitu sebesar 2,4\% dari tahun sebelumnya. Pada tahun 2017, rata-rata ROA meningkat sebesar $1,1 \%$ dan kembali mengalami penurunan di tahun 2018 dan 2019, yaitu sebesar $2,7 \%$ dan $0.8 \%$. Dari persentase rata-rata $\mathrm{ROA}$ tersebut, terlihat bahwa persentase penurunan lebih besar jika dibandingkan dengan persentase peningkatannya. Bahkan pada tahun 2018, ROA mengalami penurunan paling besar. Penurunan ROA yang rendah tersebut disebabkan karena kinerja perusahaan konstruksi pada tahun 2018 mengalami perlambatan pertumbuhan.

Menurut Kasmir (2013 : 89), terdapat beberapa faktor yang dapat mempengaruhi profitabilitas yaitu: margin laba bersih, perputaran total aktiva, laba bersih, penjualan, total aktiva, aktiva tetap, aktiva lancar, dan total biaya. Semakin tinggi dana modal kerja maka akan meningkatkan laba (profitabilitas) perusahaan. Tingginya perputaran modal kerja akan mempengaruhi tingkat pengembalian perusahaan, sehingga dengan demikian perusahaan akan memperoleh keuntungan dengan cepat. Semakin cepat perputaran modal kerja, menunjukkan bahwa baiknya kinerja perusahaan dalam mengelola aset yang ada.

Sartono (2010) menyebut bahwa jika perusahaan memiliki likuiditas yang tinggi akan mempengaruhi profit yang diperoleh. Tingkat likuiditas yang tinggi memudahkan bagi 
perusahaan untuk melakukan pembagian dividen dalam bentuk uang tunai, sehingga menarik investor dalam menanamkan modalnya. Sementara Riyanto dalam Sulindawati (2017:140) menyatakan bahwa solvabilitas dapat mempengaruhi profitabilitas, dimana solvabilitas yang tinggi berarti semakin besar biaya yang harus ditanggung perusahaan untuk membayar bunga sehingga dapat mengurangi profitabilitas perusahaan.

Penelitian yang di lakukan oleh Suryaningsih (2019) menunjukkan bahwa likuiditas tidak mempengaruhi profitabilitas, sementara solvabilitas mempengaruhi profitabilitas secara signifikan. Hasil Penelitian Sudarisman (2019) menunjukkan bahwa Working Capital Turnover Ratio (WCTR) berpengaruh positif signifikan terhadap ROA dan variabel Working Capital Total Asset (WCTA) juga berpengaruh positif signifikan terhadap ROA perusahaan. Sementara penelitian Putri (2018) menunjukkan bahwa Total Assets Turnover tidak berpengaruh terhadap Return On Assets Perusahaan. Sedangkan Working Capital Turnover menunjukkan pengaruh yang negatif tidak signifikan terhadap Return On Assets.

Berdasarkan uraian latar belakang dan adanya fenomena pada sektor konstruksi bangunan dan didukung dengan adanya research gap maka peneliti tertarik untuk melakukan penelitian dengan judul "Analisis Pengaruh Aktivitas, Likuiditas dan Solvabilitas Terhadap Profitabilitas Pada Perusahaan Konstruksi dan Bangunan Yang Terdaftar Di Bursa Efek Indonesia Periode 2015-2019.

\subsection{Masalah}

Berdasarkan uraian di atas rumusan masalah dalam penelitian ini adalah 1) apakah aktivitas berpengaruh terhadap profitabilitas pada perusahaan konstruksi dan bangunan yang terdaftar di Bursa Efek Indonesia periode 2015-2019?, 2) apakah likuiditas berpengaruh terhadap profitabilitas pada perusahaan konstruksi dan bangunan yang terdaftar di Bursa Efek Indonesia periode 2015-2019?, dan 4) apakah solvabilitas berpengaruh terhadap profitabilitas pada perusahaan konstruksi dan bangunan yang terdaftar di Bursa Efek Indonesia periode 2015-2019?

\subsection{Tujuan Penelitian}

Tujuan dari penelitian ini adalah untuk mengetahui:

1) Pengaruh aktivitas terhadap profitabilitas pada perusahaan konstruksi dan bangunan yang terdaftar di Bursa Efek Indonesia periode 2015-2019?

2) Pengaruh likuiditas terhadap profitabilitas pada perusahaan konstruksi dan bangunan yang terdaftar di Bursa Efek Indonesia periode 2015-2019?

3) Pengaruh solvabilitas terhadap profitabilitas pada perusahaan konstruksi dan bangunan yang terdaftar di Bursa Efek Indonesia periode 2015-2019?

\section{TINJAUAN PUSTAKA}

\subsection{Profitabilitas}

Profitabilitas ialah kemampuan perusahaan untuk memperoleh laba. Laba terdiri dari laba kotor, laba operasi, dan laba bersih. Manajemen harus mampu meningkatkan pendapatan (revenue) dan mengurangi semua beban (expense) atas pendapatan agar diperoleh laba yang tinggi (Halim, 2015:63). Artinya perusahaan harus mampu memperluas 
pangsa pasar dengan tingkat harga kompetitif dan tidak melakukan aktivitas yang tidak memberikan nilai tambah. Sementara Sudana (2012:22) menyatakan bahwa profitabilitas adalah ukuran untuk menilai kemampuan perusahaan dalam mendapatkan keuntungan dengan memanfaatkan keuntungan dengan memanfaatkan sumber daya yang dimiliki perusahaan seperti aktiva, modal, atau penjualan perusahaan. Menurut Munawir (2014:33) profitabilitas adalah ukuran yang menilai kemampuan perusahaan dalam menghasilkan

laba selama periode tertentu. Profitabilitas mengukur sukses tidaknya perusahaan dalam menggunakan aktiva yang ada secara produktif. Berdasarkan pengertian diatas menunjukkan bahwa profitabilitas adalah menunjukkan kinerja perusahaan untuk menghasilkan laba dengan sumber daya yang dimiliki.

\subsection{Modal Kerja}

Modal kerja adalah investasi perusahaan dalam jangka pendek yang meliputi kas, surat-surat berharga, piutang dan persediaan. Modal kerja dapat dibagi menjadi modal kerja kotor dan modal kerja bersih. Modal kerja kotor merupakan jumlah harta lancar perusahaan, sedangkan modal kerja bersih merupakan aset lancar dikurangi kewajiban lancar. Kedua modal kerja tersebut harus dikelola secara profesional agar bisnis berjalan lancar. Weston dan Brigham dalam Utari (2014:89). Sementara Ambarwati (2010:112) menyatakan bahwa modal kerja adalah aktiva lancar yang jumlahnya harus terjaga agar operasional perusahaan berjalan lancar dan diperoleh laba yang diinginkan. Weston dan Brigham dalam Utari (2014:90), menjelaskan bahwa ketidakmampuan memperoleh laba bersih akibat dari total beban (total expense) lebih besar daripada total pendapatan (total revenue). Perusahaan yang demikian adalah perusahaan yang tidak memiliki pangsa pasar luas, kalah bersaing dan tidak efisien. Ketidakefisienan ditunjukkan pada total beban yang besar dan ketidakmampuan memiliki pangsa pasar yang ditunjukkan dari total pendapatan yang kecil.

Cara perusahaan untuk meningkatkan keuntungan (profit) adalah dengan manajemen modal kerja yang baik. Efisiensi modal kerja suatu perusahaan dapat dilihat dari rasio yang digunakan, yaitu rasio perputaran modal kerja (Working Capital Turnover). Rasio ini memperlihatkan efektivitas dalam penggunaan modal kerja dalam menghasilkan penjualan. Semakin tinggi dana yang tertanam dalam modal kerja maka akan memudahkan perusahaan dalam meningkatkan keuntungannya (profitabilitas). Perputaran modal kerja yang besar dan cepat akan mempengaruhi tingkat pengembalian perusahaan, sehingga semakin cepat pula perusahaan dalam memperoleh keuntungan. Semakin cepat modal kerja berputar, memperlihatkan adanya pengelolaan aset yang baik. (Kasmir, 2012:393). Hasil penelitian yang sejalan dengan teori diatas adalah penelitian Ambarwati, dkk (2015) hasil penelitian menunjukkan modal kerja (net working capital to total asset) memiliki pengaruh yang positif dan signifikan terhadap profitabilitas. Artinya bahwa perputaran modal kerja yang semakin cepat, akan meningkatkan keuntungan yang semakin besar, sehingga dapat meningkatkan profitabilitas perusahaan. 


\subsection{Likuiditas}

Likuiditas adalah ukuran untuk menilai kemampuan perusahaan dalam memenuhi kewajiban lancarnya, baik itu kewajiban kepada pihak internal perusahaan maupun eksternal perusahaan (Kasmir, 2012:129). Sementara menurut Munawir (2010) likuiditas adalah ukuran untuk menilai seberapa besar kemampuan perusahaan untuk memenuhi kewajiban keuangan pada saat jatuh tempo. Menurut Sartono (2012:116) likuiditas menggambarkan kemampuan perusahaan untuk membayar kewajiban finansial jangka pendek tepat pada waktunya. Dari uraian diatas, artinya bahwa perusahaan yang mampu membayar kewajiban lancar pada saat jatuh tempo memiliki tingkat likuiditas yang baik sehingga perusahaan mampu dengan cepat memperoleh laba dari perputaran cashflow perusahaan tersebut.

Hasil penelitian yang sejalan dengan teori diatas adalah penelitian Sari (2017) menyatakan bahwa likuiditas mempengaruhi profitabilitas secara signifikan. Hal ini disebabkan karena likuiditas yang menggambarkan perbandingan nilai aktiva lancar dengan hutang lancar perusahaan tergambar positif. Semakin tinggi likuiditas perusahaan menunjukkan rendahnya beban bunga yang ditanggung perusahaan sehingga tingkat profitabilitas yang diperoleh semakin tinggi. Likuiditas yang tinggi selalu menguntungkan dan kesempatan perusahaan untuk berinvestasi semakin tinggi pula.

\subsection{Solvabilitas}

Solvabilitas menunjukkan sejauh mana aset yang dimiliki oleh perusahaan dibiayai dengan hutang. Menurut Riyanto (2010:32), Solvabilitas adalah ukuran seberapa besar kemampuan perusahaan dalam memenuhi kewajiban keuangannya apabila perusahaan dibubarkan. Solvabilitas adalah kemampuan perusahaan untuk membayar seluruh kewajiban jangka pendek dan jangka panjang. Dari uraian diatas dapat disimpulkan bahwa solvabilitas merupakan sebuah ukuran bagaimana perusahaan membayar seluruh dengan aktiva yang dimiliki. Perusahaan dengan solvabilitas yang tinggi, maka berdampak besar pada risiko kerugian, tetapi ada kesempatan untuk menghasilkan laba yang besar. Sebaliknya perusahaan dengan solvabilitas yang rendah, maka risiko kerugian yang dihadapi lebih kecil. Dampak ini juga mengakibatkan rendahnya tingkat return pada saat perekonomian tinggi (Kasmir (2018:152).

Hasil penelitian Yuniastuti (2016) pada Perusahaan Transportasi yang terdaftar di Bursa Efek Indonesia tahun 2016. Diketahui bahwa faktor solvabilitas yang diproksikan dengan DAR berpengaruh negatif signifikan terhadap profitabilitas yang diproksikan dengan ROA. Dengan kata lain peningkatan DAR mendorong adanya penurunan ROA. Hasil tersebut menunjukkan bahwa semakin besar hutang perusahaan, semakin tinggi pula beban tetap yang ditanggung perusahaan dan komitmen pembayaran kembali yang ditimbulkan. 




\section{Gambar 2. Kerangka Konsep}

Berdasarkan kerangka konsep di atas, dapat dirumuskan hipotesis penelitian sebagai berikut:

$\mathrm{H} 1$ : Aktivitas berpengaruh positif terhadap profitabilitas perusahaan

H2 : Likuiditas berpengaruh positif terhadap profitabilitas perusahaan

H3 : Solvabilitas berpengaruh negatif terhadap profitabilitas perusahaan

\section{METODE PENELITIAN}

\subsection{Populasi}

Populasi dalam penelitian ini adalah perusahaan konstruksi dan bangunan yang terdaftar di Bursa Efek Indonesia Periode 2015 - 2019. Jumlah populasi adalah sebanyak 19 perusahaan.

Tabel 1. Daftar Perusahaan Konstruksi dan Bangunan yang Menjadi Populasi

\begin{tabular}{cll}
\hline No. & Kode & \multicolumn{1}{c}{ Nama Perusahaan } \\
\hline 1 & ACST & Acset Indonusa, Tbk \\
2 & ADHI & Adhi Karya (Persero) Tbk \\
3 & BKDP & Bukit Darmo Property Tbk \\
4 & CSIS & Cahayasakti Investindo Sukses Tbk \\
5 & DGIK & Nusa Konstruksi Enjiniring Tbk \\
6 & IDPR & Indonesia Pondasi Raya Tbk \\
7 & JKON & Jaya Konstruksi Manggala Pratama Tbk \\
8 & MTRA & Mitra Pemuda Tbk \\
9 & MYRX & Hanson Internasional Tbk \\
10 & NRCA & Nusa Raya Cipta Tbk \\
11 & PBSA & Paramita Bangun Sarana Tbk \\
12 & PTPP & PP (Persero) Tbk \\
13 & SKRN & Superkrane Mitra Utama Tbk \\
14 & SSIA & Surya Semesta Internusa Tbk \\
15 & TOPS & Totalindo Eka Persada Tbk \\
16 & TOTL & Total Bangun Persada Tbk \\
17 & WEGE & Wijaya Karya Bangunan Gedung Tbk \\
18 & WIKA & Wijaya Karya (Persero) Tbk \\
19 & WSKT & Waskita Karya (Persero) Tbk \\
\hline \multicolumn{3}{c}{ Sumber : (www.edusaham.com) }
\end{tabular}




\subsection{Sampel}

Pengambilan sampel menggunakan pendekatan non probability sampling dengan menggunakan metode purposive sampling yaitu teknik penentuan sampel dengan pertimbangan tertentu yang ditentukan oleh peneliti. Kriteria dan jumlah sampel dalam penelitian ini sebagai berikut:

\begin{tabular}{llc}
\hline No. & \multicolumn{1}{c}{ Kriteria } & Jumlah \\
\hline 1 & $\begin{array}{l}\text { Perusahaan konstruksi dan bangunan yang terdaftar di } \\
\text { Bursa Efek Indonesia periode 2015-2019 }\end{array}$ & 19 \\
\hline 2 & $\begin{array}{l}\text { Perusahaan konstruksi dan bangunan yang memberikan } \\
\text { laporan keuangan secara lengkap di Bursa Efek Indonesia } \\
\text { selama periode 2015-2019 }\end{array}$ & 13 \\
\hline & Jumlah N =13 x 5 & 65 \\
\hline
\end{tabular}

\subsection{Teknik Pengumpulan Data}

Teknik pengumpulan data menggunakan dokumentasi dari data sekunder yang dikumpulkan kemudian ditelaah lebih lanjut. Data yang dikumpulkan berupa data WCT, CR, DAR, dan ROA tahunan selama periode 2015-2019.

\subsection{Metode Analisis Data (Analisis Regresi Data Panel)}

Untuk menganalisis hubungan antar variabel yang diteliti dalam penelitian ini menggunakan regresi data panel dengan program Eviews 9.0 dan SPSS 25. Dalam penelitian ini menggunakan data panel yang menggabungkan data cross section yang terdiri dari 13 perusahaan dan data time series terdiri dari data tahun 2015 sampai dengan tahun 2019. Regresi data panel merupakan teknik regresi yang menggabungkan data time series dengan cross section.

\section{HASIL DAN PEMBAHASAN}

\subsection{Deskriptif Statistik}

Guna mendapatkan gambaran terhadap variabel-variabel yang diteliti maka perlu dilakukan analisis deskriptif. Pada analisis ini akan dilihat beberapa hal dari masing-masing model yakni nilai minimum dan maksimum serta rata-rata dan deviasi standar dari tiap-tiap variabel penelitian. Adapun hasil pengolahan data ditunjukkan oleh tabel di bawah ini:

Tabel 2. Statistika Deskriptif Variabel-Variabel Penelitian

\begin{tabular}{lcccc}
\hline & ROA & WCT & CR & DAR \\
\hline Mean & 0.042308 & 9.874615 & 1.547077 & 0.594615 \\
Median & 0.040000 & 2.510000 & 1.420000 & 0.640000 \\
Maximum & 0.160000 & 383.7500 & 3.140000 & 0.970000 \\
Minimum & -0.110000 & -8.810000 & 0.280000 & 0.000000 \\
Std. Dev. & 0.040803 & 47.77285 & 0.522980 & 0.165228 \\
Skewness & -0.537642 & 7.558516 & 0.659835 & -0.766226 \\
Kurtosis & 6.531384 & 59.54449 & 4.284436 & 4.231155 \\
Jarque-Bera & 36.90621 & 9278.220 & 9.184783 & 10.46541 \\
Probability & 0.000000 & 0.000000 & 0.010129 & 0.005339 \\
Sum & 2.750000 & 641.8500 & 100.5600 & 38.65000 \\
Sum Sq. Dev. & 0.106554 & 146063.7 & 17.50454 & 1.747215 \\
\hline Observations & 65 & 65 & 65 & 65 \\
\hline
\end{tabular}

Sumber: Output Eviews 9 
Berdasarkan tabel 2 dapat tergambar Return On Asset (ROA) memiliki nilai rata-rata 0.042308 dan standar deviasi 0.040803 . Nilai standar deviasi yang lebih rendah dari nilai rata-rata mencerminkan bahwa data variabel ROA terdistribusi normal. Working Capital Turnover (WCT) memiliki nilai rata-rata 9.874615 dan standar deviasi 47.77285. Nilai standar deviasi yang lebih besar dari nilai rata-rata mencerminkan data tidak terdistribusi secara normal. Current Ratio (CR) memiliki nilai rata-rata 1.547077 dan standar deviasi 0.165228 . Nilai standar deviasi yang lebih rendah dari nilai rata-rata mencerminkan bahwa data variabel CR terdistribusi normal. Debt to Asset Ratio (DAR) memiliki nilai rata-rata 0.594615 dan standar deviasi 0.522980 . Nilai standar deviasi yang lebih rendah dari nilai rata-rata mencerminkan bahwa data variabel $\mathrm{CR}$ terdistribusi normal.

\subsection{Pengujian Asumsi Klasik}

\subsubsection{Uji Normalitas}

Tabel 3. Uji Normalitas

One-Sample Kolmogorov-Smirnov Test

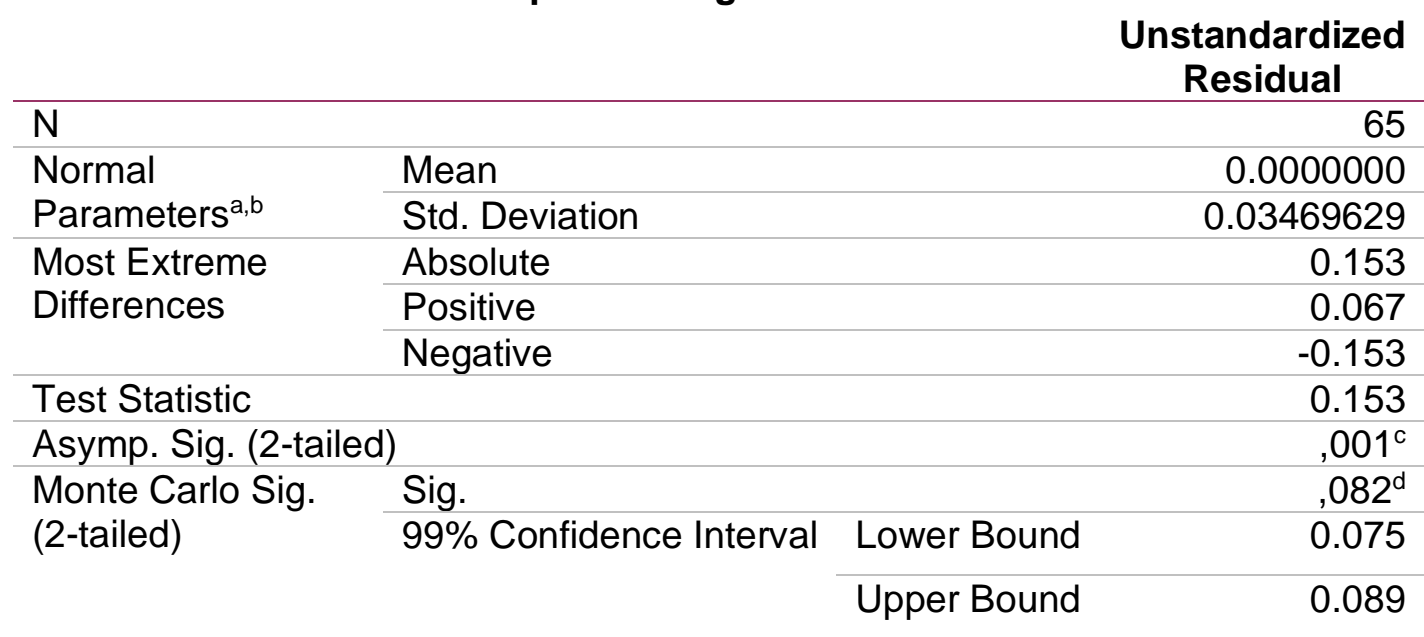

Sumber: Output SPSS 25

Dari tabel 3 diatas, dengan menggunakan One Sample KS Monte Carlo didapatkan nilai signifikasi lebih besar dari 0.05 yaitu 0.089 , Sehingga didapat kesimpulan bahwa data penelitian ini terdistribusi secara normal.

\subsubsection{Uji Multikolineritas}

Tabel 4. Hasil Perhitungan Koefisien Korelasi

\begin{tabular}{cccc} 
& WCT & CR & DAR \\
\hline \hline WCT & 1.000000 & -0.154838 & 0.146337 \\
CR & -0.154838 & 1.000000 & -0.461571 \\
DAR & 0.146337 & -0.461571 & 1.000000 \\
\hline \hline \multicolumn{4}{l}{ Sumber : Output Eviews 9}
\end{tabular}

Dari tabel 4 di atas terlihat nilai korelasi dari ketiga variabel independen diatas mempunyai nilai korelasi lebih rendah dari $0.08(80 \%)$ yaitu $-0.154838,-0.146337$ dan -0.461571 , maka dapat disimpulkan tidak terdapat multikolinearitas. 


\subsubsection{Uji Heteroskedastisitas}

\section{Tabel 5. Uji Heteroskedastisitas}

Dependent Variable: RESABS

Method: Panel Least Squares

Date: 08/14/20 Time: 17:07

Sample: 20152019

Periods included: 5

Cross-sections included: 13

Total panel (balanced) observations: 65

\begin{tabular}{crrrr}
\hline Variable & Coefficient & Std. Error & t-Statistic & Prob. \\
\hline C & 0.024490 & 0.019394 & 1.262721 & 0.2115 \\
WCT & $-2.68 \mathrm{E}-05$ & $6.43 \mathrm{E}-05$ & -0.416298 & 0.6787 \\
CR & 0.003925 & 0.006554 & 0.598831 & 0.5515 \\
DAR & -0.008800 & 0.020718 & -0.424741 & 0.6725 \\
\hline
\end{tabular}

Sumber : Output Eviews 9

Dari tabel 5 dapat dilihat bahwa nilai probabilitas variabel independen WCT, CR dan DAR lebih besar dari nilai $\alpha=0.05$, maka dapat disimpulkan tidak ada masalah heteroskedastisitas.

\subsubsection{Uji Autokorelasi}

Tabel 6. Uji Autokorelasi dengan Durbin Watson

Weighted Statistics

\begin{tabular}{llll}
\hline \hline R-squared & 0.258848 & Mean dependent var & 0.027917 \\
Adjusted R-squared & 0.222398 & S.D. dependent var & 0.036716 \\
S.E. of regression & 0.032377 & Sum squared resid & 0.063945 \\
F-statistic & 7.101445 & Durbin-Watson stat & $\mathbf{1 . 6 1 7 0 6 1}$ \\
Prob(F-statistic) & 0.000361 & & \\
\hline \hline
\end{tabular}

Sumber: Output Eviews 9

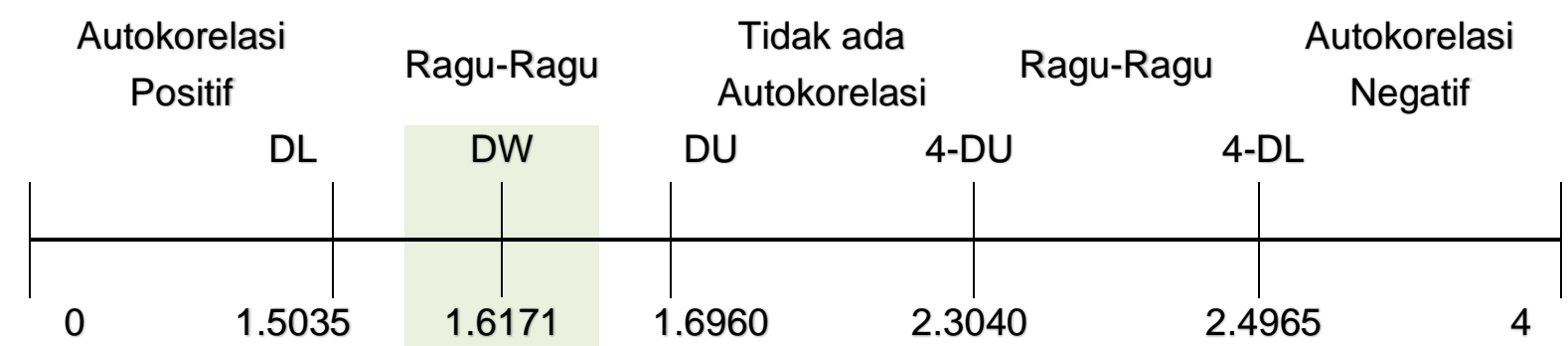

\section{Gambar 2. Aturan Membandingkan Uji Durbin-Watson dengan Tabel Durbin-Watson}

Dari tabel 6 diatas, berdasarkan tabel Durbin Watson, Nilai DW= 1.6171 berada diantara nilai $\mathrm{DL}$ dan $\mathrm{DU}$ nilai $\mathrm{DL}=1.5035$ dan $\mathrm{DU}=1.6960$., hal itu menunjukkan bahwa belum dapat disimpulkan apakah terjadi autokorelasi atau tidak, maka dilakukan Uji Runtest dengan bantuan program SPSS dengan hasil sebagai berikut: 


\section{Tabel 7. Runs Test}

\begin{tabular}{lr} 
& Unstandardized Residual \\
\hline Test Value &,- 00270 \\
\hline Cases $<$ Test Value & 32 \\
\hline Cases $>=$ Test Value & 33 \\
\hline Total Cases & 65 \\
\hline Number of Runs & 29 \\
\hline Z & $-1,123$ \\
\hline Asymp. Sig. (2-tailed) &, 261 \\
\hline a. Median $\quad$ \\
\multicolumn{1}{|c}{ Sumber : Output SPSS 25 } \\
\hline
\end{tabular}

Berdasarkan output diatas, diketahui nilai asymptotic significance 2-tailed bernilai 0,261 dan lebih besar dari nilai 0,05 maka dapat dinyatakan bahwa tidak terjadi autokorelasi pada data penelitian ini.

\subsection{Analisis Regresi Data Panel}

Berdasarkan pengujian yang dilakukan, model yang paling tepat digunakan adalah model Random Effects.

\section{Tabel 8. Hasil Regresi Data Panel dengan Random Effects}

Dependent Variable: ROA

Method: Panel EGLS (Cross-section random effects)

Date: 08/14/20 Time: 16:34

Sample: 20152019

Periods included: 5

Cross-sections included: 13

Total panel (balanced) observations: 65

Swamy and Arora estimator of component variances

\begin{tabular}{cccrc}
\hline \hline Variable & Coefficient & Std. Error & t-Statistic & Prob. \\
\hline \hline C & -0.019651 & 0.030549 & -0.643255 & 0.5225 \\
WCT & 2.988352 & 2.912458 & 1.025599 & 0.3091 \\
CR & 0.043791 & 0.010771 & 4.065472 & 0.0001 \\
DAR & -0.011306 & 0.032653 & -0.346243 & 0.7304 \\
\hline \hline
\end{tabular}

Sumber: Output Eviews 9

Dari tabel 8 diatas, nilai koefisien Working Capital Turnover (WCT) sebesar 2.988352 yang menunjukkan bahwa WCT berpengaruh positif terhadap Return On Asset (ROA), nilai koefisien Current Ratio (CR) sebesar 0.043791 yang menunjukkan bahwa CR berpengaruh positif terhadap ROA, sedangkan nilai koefisien Debt to Asset Ratio (DAR) sebesar -0.011306 yang menunjukkan bahwa DAR berpengaruh negatif terhadap ROA.

\subsection{Uji Kelayakan Model}

Uji F dilakukan untuk melihat pengaruh dari seluruh variabel independen secara bersama-sama (simultan) terhadap variabel dependen. Pada tabel 8 , Nilai f-statistik sebesar 
7.101445. Nilai ini lebih besar dibandingkan dengan F-tabel yaitu sebesar 2.75 atau probabilitas $(\mathrm{F}$-statistik $)=0.000361$ lebih kecil dari $\alpha=0.05$ yang berarti $\mathrm{Ho}$ ditolak. Maka dapat disimpulkan bahwa variabel Working Capital Turnover, Current Ratio dan Debt to Asset Ratio berpengaruh secara simultan terhadap Return on Asset.

\subsection{Pengujian Hipotesis (Uji-t)}

Uji-t dilakukan untuk melihat apakah masing-masing dari variabel independen mempengaruhi variabel dependen secara signifikan atau tidak. Berikut adalah hasil pengujian hipotesis dari masing-masing variabel independen.

\section{Pengaruh Working Capital Turnover (WCT) terhadap Return On Asset (ROA)}

Berdasarkan tabel 8, nilai t-statistik Working Capital Turnover (WCT) sebesar 1.02560 lebih kecil dari nilai t-tabel yaitu 1.67022 atau probabilitas t statistik $=0.3091$ lebih besar dari $\alpha=0.05$ yang berarti HO diterima. Hasil tersebut menunjukkan bahwa Working Capital Turnover (WCT) berpengaruh positif tetapi hasilnya tidak signifikan terhadap Return on Asset (ROA).

\section{Pengaruh Current Ratio (CR) terhadap Return On Asset (ROA)}

Berdasarkan tabel 8, nilai t-statistik Current Ratio (CR) sebesar 4.065472 lebih kecil dari nilai t-tabel yaitu 1.67022 atau probabilitas $t$ statistik $=0.0001$ lebih kecil dari $\alpha=$ 0.05 yang berarti HO ditolak. Maka dapat disimpulkan bahwa Current Ratio (CR) berpengaruh positif dan signifikan terhadap Return on Asset (ROA).

\section{Pengaruh Debt to Asset Ratio (DAR) terhadap Return On Asset (ROA)}

Berdasarkan tabel 8, nilai t-statistik Debt to Asset Ratio (DAR) sebesar -0.346243 lebih kecil dari nilai t-tabel yaitu 1.67022 atau probabilitas t statistik $=0.7304$ lebih besar dari $\alpha=0.05$ yang berarti $\mathrm{HO}$ diterima. Maka dapat disimpulkan bahwa Current Ratio (CR) berpengaruh negatif dan tidak signifikan terhadap Return on Asset (ROA).

\subsection{Pembahasan}

Sebelumnya telah dijelaskan mengenai hasil penelitian mulai dari model regresi data panel terpilih yaitu model random effect, pengujian asumsi klasik sampai dengan uji signifikansi (Uji-t dan Uji-f). Dari hasil penelitian tersebut, ringkasan mengenai hubungan dan signifikansi dari WCT, CR dan DAR sebagai variabel independen terhadap ROA sebagai variabel dependen akan disajikan pada tabel berikut:

Tabel 9. Ringkasan Hubungan dan Signifikansi Hasil Regresi Data Panel.

\begin{tabular}{ccccc}
\hline & & Hipotesis & Hasil Penelitian & Keterangan \\
\hline Variabel Dependen & ROA & & & \\
\hline \multirow{2}{*}{ Variabel Independen } & WCT & Positif & Positif & Tidak Signifikan \\
\cline { 2 - 5 } & CR & Positif & Positif & Signifikan \\
\cline { 2 - 5 } & DAR & Positif & Negatif & Tidak Signifikan \\
\hline \multicolumn{4}{c}{ Sumber : Data diolah peneliti } &
\end{tabular}

Berdasarkan tabel 9 di atas menunjukkan bahwa hasil uji hipotesis untuk variabel Aktivitas (X1) yang dihitung dengan WCT memiliki hasil positif tidak signifikan, variabel likuiditas (X2) yang dihitung dengan CR memiliki hasil positif dan signifikan, sedangkan 
variabel solvabilitas (X3) yang dihitung dengan DAR memiliki hasil negatif dan tidak signifikan. Uraian lebih lanjut dapat dilihat dan dijabarkan pada sub-sub bab berikut ini:

\subsubsection{Pengaruh Aktivitas terhadap Profitabilitas}

Berdasarkan hasil uji t didapatkan bahwa variabel aktivitas yang di hitung dengan Working Capital Turnover (WCT) berpengaruh positif namun hasilnya tidak signifikan terhadap profitabilitas yang dihitung dengan Return On Asset (ROA). Hasil yang tidak signifikan artinya data sampel dalam penelitian ini tidak mampu menjelaskan adanya keterkaitan/hubungan antar variabel. Hasil ini menunjukkan bahwa Working Capital Turnover (WCT) memiliki pengaruh namun karena ada faktor lain dalam perusahaan yang menyebabkan pengaruhnya tidak signifikan terhadap Return on Asset (ROA). Salah satunya adalah faktor biaya, besarnya biaya yang dikeluarkan perusahaan juga dapat mempengaruhi laba. Jika perputaran modal kerja tinggi namun biaya yang dikeluarkan perusahaan juga besar, maka akan berpengaruh terhadap perolehan laba perusahaan. Perusahaan dituntut lebih efektif lagi dalam mengelola modal kerjanya agar mampu menghasilkan laba yang optimal.

Hasil penelitian ini tidak sejalan dengan teori yang menyatakan bahwa semakin tinggi dana modal kerja maka akan meningkatkan laba (profitabilitas) perusahaan (Kasmir, 2012:393). Hasil penelitian ini mendukung penelitian yang dilakukan oleh Putri (2018) dimana Working Capital Turnover (WCT) berpengaruh positif tidak signifikan pada Return on Asset (ROA). Hasil Penelitian yang berbeda didapat dari Hartono dan Puspita (2018) dimana Working Capital Turnover (WCT) berpengaruh positif signifikan terhadap profitabilitas.

\subsubsection{Pengaruh Likuiditas terhadap Profitabilitas}

Berdasarkan hasil uji t didapatkan bahwa variabel likuiditas yang dihitung dengan Current Ratio berpengaruh positif dan signifikan terhadap profitabilitas yang dihitung dengan Return On Asset (ROA). Hasil penelitian ini sejalan dengan pendapat Sartono, (2010) bahwa perusahaan dengan tingkat likuiditas yang tinggi mampu memperoleh profit. Perusahaan yang mampu melunasi seluruh kewajiban lancarnya pada saat jatuh tempo menunjukkan adanya tingkat likuiditas yang baik sehingga perusahaan akan lebih cepat memperoleh laba dari perputaran cashflow perusahaan tersebut. Penelitian ini mendukung penelitian Mahardika (2016) bahwa Current Ratio (CR) memiliki pengaruh positif dan signifikan terhadap Return on Asset (ROA). Penelitian lain telah dilakukan Dewi, dkk (2015) memperoleh hasil bahwa Current Ratio (CR) berpengaruh positif dan signifikan terhadap Return on Asset (ROA).

\subsubsection{Pengaruh Solvabilitas Terhadap Profitabilitas}

Berdasarkan hasil uji t didapatkan bahwa variabel Solvabilitas yang dihitung dengan Debt to Asset Ratio berpengaruh negatif tidak signifikan terhadap profitabilitas Return On Asset $(\mathrm{ROA})$. Hasil yang tidak signifikan artinya data sampel dalam penelitian ini tidak mampu menjelaskan adanya keterkaitan/hubungan antar variabel. Hasil ini mengindikasikan bahwa Solvabilitas (DAR) bukan salah satu faktor yang mempengaruhi profitabilitas $(R O A)$ pada perusahaan konstruksi dan bangunan yang terdaftar di BEI 
periode 2015-2019. Jika hasil perhitungan perusahaan menunjukkan rasio solvabilitas yang tinggi, maka akan berdampak pada risiko kerugian yang lebih besar, akan tetapi ada kesempatan untuk mendapatkan laba yang lebih besar. Seperti yang terjadi pada penelitian ini, DAR berpengaruh negatif dan tidak signifikan terhadap ROA. Hal itu karena Rasio DAR rendah sehingga perusahaan tidak ada kesempatan untuk mendapatkan return dari aktiva yang dimiliki.

Hasil penelitian ini berbeda dengan pendapat bahwa solvabilitas mengukur sejauh mana aset yang dimiliki perusahaan didanai dari pinjaman (Kasmir, 2018:151-152). tingginya rasio solvabilitas, artinya terlalu banyak dibiaya oleh utang, sehingga akan menyulitkan bagi perusahaan untuk mencari pinjaman baru karena dikhawatirkan tidak mampu melunasi kewajiban dengan aset yang dimilikinya. Demikian pula sebaliknya rasio yang rendah, artinya pembiayaan dari utang juga semakin kecil.

Hasil ini sejalan dengan Kamal (2016) bahwa Debt to Asset Ratio (DAR) berpengaruh negatif tidak signifikan terhadap Return on Asset (ROA). Namun berbeda dengan hasil penelitian Sutopo (2015) yang menyatakan bahwa solvabilitas berpengaruh negatif dan signifikan terhadap Return on Asset (ROA).

\section{PENUTUP}

\subsection{Kesimpulan}

Berdasarkan hasil analisis dan pembahasan data, peneliti memperoleh kesimpulan yang dapat diambil dari penelitian mengenai Pengaruh Aktivitas, Likuiditas, dan Solvabilitas terhadap Return On Asset (ROA) pada perusahaan konstruksi dan bangunan sebagai berikut:

1) Hasil dari penelitian ini menunjukkan bahwa Aktivitas yang dihitung dengan Working Capital Turnover (WCT) berpengaruh positif tidak signifikan terhadap Return On Assets (ROA) pada perusahaan konstruksi dan bangunan yang terdaftar di BEl periode 2015-2019. Hasil tersebut tidak sejalan dengan hipotesis peneliti yang menyatakan bahwa Working Capital Turnover (WCT) berpengaruh positif terhadap ROA.

2) Hasil dari penelitian ini menunjukkan bahwa Likuiditas yang dihitung dengan Current Ratio (CR) berpengaruh positif dan signifikan terhadap Return On Assets pada perusahaan konstruksi dan bangunan yang terdaftar di BEI periode 2015-2019. Hasil tersebut sejalan dengan hipotesis peneliti yang menyatakan bahwa Current Ratio (CR) berpengaruh positif terhadap ROA.

3) Hasil dari penelitian ini menunjukkan bahwa Solvabilitas yang dihitung dengan Debt to Asset Ratio (DAR) berpengaruh negatif tidak signifikan terhadap Return On Assets (ROA) pada perusahaan konstruksi dan bangunan yang terdaftar di BEl periode 20152019. Hasil tersebut sejalan dengan hipotesis peneliti yang menyatakan bahwa Debt to Asset Ratio (DAR) berpengaruh negatif terhadap ROA.

\subsection{Saran}

Berdasarkan hasil dari rangkaian pengujian data yang diperoleh dalam penelitian ini peneliti memberikan beberapa saran sebagai berikut :

1) Bagi Perusahaan 
Bagi perusahaan konstruksi dan bangunan di Indonesia harus memperhatikan kegiatan operasi perusahaan itu sendiri terutama dalam pengelolaan aset yang dimiliki oleh perusahaan. Debt to Asset Ratio menurun bisa disebabkan adanya total hutang yang menurun dan tidak efektifnya pengolahan aktiva sehingga laba belum maksimal dan laba bersih pun ikut menurun.

2) Bagi Peneliti Selanjutnya

Bagi peneliti selanjutnya dapat dijadikan pembanding dan acuan khususnya dalam penelitian tentang pengaruh aktivitas, likuiditas dan solvabilitas terhadap tingkat profitabilitas perusahaan khususnya pada sektor konstruksi, serta dapat melakukan penelitian untuk variabel lain yang berpengaruh terhadap profitabilitas perusahaan.

\section{DAFTAR PUSTAKA}

Ambarwati, N. sagita, Yuniarta, G. A., \& Sinarwati, N. K. (2015). Pengaruh modal kerja, likuiditas, aktivitas dan ukuran perusahaan terhadap profitabilitas pada perusahaan manufaktur yang terdaftar di BEI. E-Journal S1 AK Universitas Pendidikan Ganesha.

Ambarwati, S. D. A. (2010). Manajemen Keuangan Lanjut. Graha IImu.

Ghozali, I. (2016). Aplikasi Analisis Multivariete Dengan Program IBM SPSS 23. Universitas Diponegoro.

Halim, D. A. (2015). Manajemen Keuangan Bisnis. Mitra Wacana Media.

Kamal, M. B. (2016). Pengaruh Receivable Turn over dan Debt to Asset Ratio terhadap Return on Asset pada perusahaan pertanian yang terdaftar di BEl. Jurnal IImiah Manajemen Dan Bisnis.

Kasmir. (2012). Analisis Laporan Keuangan. PT. Raja Grafindo Persada.

Kasmir. (2018). Analisis Laporan Keuangan. PT Raja Grafindo Persada.

Mahardika, P. A. (2016). Pengaruh Current Ratio dan Debt to Equity Ratio terhadap Return On Assets. Jurnal Widyakala.

Munawir. (2014). Analisa Laporan Keuangan. Liberty.

Puspita, D. A., \& Hartono, U. (2018). Pengaruh perputaran modal kerja, ukuran perusahaan, leverage dan likuiditas terhadap profitabilitas perusahaan animal feed di BEI periode 2012-2015. Jurnal IImu Menajemen.

Putri. (2018). Pengaruh Aktivitas terhadap profitabilitas perusahaan konstruksi dan bangunan di Indonesia. Jurnal Seminar Nasional STMIK Royal SUMUT.

Riyanto, B. (2010). Dasar-Dasar Pembelanjaan Perusahaan. BPFE.

Sari, S. W. (2017). Pengaruh struktur modal, likuiditas terhadap profitabilitas perusahaan makanan dan minuman di BEI. Jurnal IImu Dan Riset Manajemen.

Sartono, A. (2012). Manajemen Keuangan Teori dan Aplikasi. BPFE.

Sudana, I. M. (2012). Manajemen Keuangan Perusahaan Teori dan Praktik. Erlangga.

Sudarisman. (2019). Analisis faktor modal kerja yang berpengaruh terhadap profitabilitas pada perusahaan jasa konstruksi yang terdaftar di BEI. Forum Ekonomi Universitas Trunajaya Bontang, 21, 235-245.

Sugiyono. (2015). Metode Penelitian Kuantitatif, Kualitatif dan R\&D. Alfabeta.

Sulindawati, N. luh G. E. (2017). Manajemen Keuangan Sebagai Dasar Pengambilan 
keputusan Bisnis. PT Raja Grafindo Persada.

Suryaningsih. (2019). Analisis Pengaruh Likuiditas dan Solvabilitas terhadap profitabilitas perusahaan konstruksi dan bangunan yang terdaftar di BEl.

Sutopo, Negoro, B. K., \& Fajria, N. L. (2015). Pengaruh Modal Kerja, Likuiditas dan Solvabilitas terhadap profitabilitas perusahaan agro di BEI. E-Journal Manajemen BRANCHMARCK, 1.

Sutrisno. (2012). Manajemen Keuangan Teori Konsep dan Aplikasi. EKONISIA.

Utari, D., Purwanti, A., \& Prawironegoro, D. (2014). Manajemen Keuangan. Mitra Wacana Media.

Yuniastuti, R. M. (2016). Pengaruh Dominan Cash Ratio Dan Debt To Asset Ratio Terhadap Return On Equity Dan Return On Assets Pada Perusahaan Transportasi Di Bursa Efek Indonesia. Jurnal Manajemen Magister Darmajaya, Vol 02. No.01. hal 95-104

www.britama.com. (n.d.).

www.cekindo.com. (n.d.).

www.edusaham.com. (n.d.).

www.marketbisnis.com. (n.d.). 